\title{
Author Correction: A guide to ancient protein studies
}

Jessica Hendy (D), Frido Welker (1), Beatrice Demarchi (1D, Camilla Speller (1D, Christina Warinner (10) and Matthew J. Collins (1)

Correction to: Nature Ecology \& Evolution https://doi.org/10.1038/s41559-018-0510-x, published online 26 March 2018.

In the version of this Perspective originally published, in the third paragraph of the section 'Selection and sampling', the sentence beginning 'Pyrolysis-gas chromatography' should have also referred to high-performance liquid chromatography; the sentence has now been amended to read 'Pyrolysis-gas chromatography/mass spectrometry (py-GC/MS) and high-performance liquid chromatography (HPLC) can be used to detect the presence of amino acids ${ }^{62}$ in any putative proteinaceous sample.'

Published online: 4 June 2018

https://doi.org/10.1038/s41559-018-0590-7 